\title{
A Case Study into the Motivations, Challenges and Opportunities in Crowdfunding: An Entrepreneurial Perspective
}

\author{
Chun Yan Wang, \\ Kate Johnston, \\ Maeve Caraher
}

\section{Dundalk Institute of Technology, Ireland}

\begin{abstract}
This case describes the motivation, challenges, and opportunities the founder of an innovative cycling product experienced as he attempted to use crowdfunding as a platform to establish and grow his business idea. The case begins with a brief overview of how the entrepreneur came up with the idea and the journey from product concept to product launch. The decision to crowdfund the idea is explained and the challenges and opportunities in trying to navigate the crowdfunding arena are explored; from selecting a suitable crowdfunding platform to the launch and management of the final campaign. Despite the fact the campaign failed to raise the funding target, the media coverage from the crowdfunding campaign led to a number of significant business avenues, which ultimately helped launch the product onto the marketplace. The case examines these events and closes as the entrepreneur reflects on the lessons learnt from the experience and his advice going forward to anyone considering crowdfunding.
\end{abstract}

Keywords: Crowdfunding, Innovation, Case Study, Entrepreneurship 


\section{Introduction}

In the new digital economy, crowdfunding has emerged as a powerful and disruptive tool transforming the financial landscape for entrepreneurs worldwide. Across numerous continents and sectors as diverse as information technology, creative arts, social and community groups, have effusively embraced this new funding source. According to the Crowdfunding Industry Report (Massolution 2015), crowdfunding platforms raised approximately \$6.1billion in 2013, compared to \$1.47billion in 2011. Recent data suggests that the sector, as of 2019 , was valued at close to $\$ 14$ billion (Statistia, 2020). More recent market forecast by Mordo Intelligence (2020) which charts the growth, trends and forecasts for the sector, suggests that the crowdfunding market is expected to grow exponentially, at a CAGR of over 16 percent over the next five (2020-2025) to a market value of $\$ 30$ billion. Kickstarter -- one of the largest crowdfunding platforms in the world -- reported that it had raised over US $\$ 5$ billion between 2009 and 2020 (Kickstarter, 2020).

Within the last decade, there has been a growing interest within the academic community into the phenomenon of crowdfunding. Studies have consistently documented that accessing finance is among the most challenging aspects in successfully establishing new entrepreneurial businesses (Belleflamme et al., 2015). When it comes to new businesses, innovative start-up generates considerable economic impact, and yet despite this, the reality is that most start-ups fail (Audretsch et al., 2020). Crowdfunding has been shown to 'democratise' access to finance on a global scale. As such, crowdfunding has the potential to increase entrepreneurship by engaging with the crowds from whom funds can be raised more effectively over traditional financial sources (Estrin et al., 2018). Studies have documented the potential of crowdfunding to overcome the 'funding gap': displacing traditional funding methods (Estrin et al, 2018; Gedda et al., 2016), and providing much needed seed capital (Belleflamme et al., 2014; Bruton et al., 2015; Lehner, 2013), particularly at the start-up stage.

One aspect of this research is to study the non-financial benefits in the form of market validation and skills development for the entrepreneurs. Numerous research indicates that by placing new ideas on a crowdfunding platform, the project becomes part of the public domain allowing entrepreneurs engage with the crowd and thereby receiving much needed feedback (Belleflamme et al., 2014; Bruton et al., 2015; Herve and Schwienbacher, 2018), improved product visibility (Burtch et al., 2013). There is also evidence to suggest that crowdfunding is also opening the door to other funding arenas (Agrawal et al., 2015) traditionally beyond the scope of start-ups.

\section{Literature Review}

Within the last five years, the proliferation of crowdfunding platforms has certainly provided new opportunities for entrepreneurs. Research suggests that in 2017, there are more than 2000 active platforms worldwide (Galkiewicz and Galkiewicz, 2018). Moreover, the outbreak of COVID-19 has seen the crowdfunding market witnessing significant growth (Mordo intelligence 2020). However, success rates among crowdfunding platforms remain relatively low. Industry backed research by Mollick

International Journal of Management and Applied Research, 2021, Vol. 8, No. 1 
(2014) based on a database from Kickstarter reported a success rate between 2009 and 2012 of 48.1 percent. Data for 2015 and 2016 indicate that success rates have actually declines to 36 percent and 32 percent respectively. Similarly, data from Indiegogo, the second largest crowdfunding platform, reported success rates to be about 33 percent (Massolution, 2015). Arguably, the growth in the number of platforms and the failure rates among campaigns are interconnected, since the growth in crowdfunding platforms while beneficial, may cause the attention of potential investors to be spread too thin.

This has led to a growing body of research which has examined crowdfunding from a supply side. Research has examined the dynamics and motivations among investors to participate in crowdfunding activities (Kuppuswamy and Bayus, 2018). Studies have identified a range of motivations that drive investors including financial returns (Shafi, 2019); participating in innovative projects (Burger and Kleinert, 2020); advancing personal growth (Wald, et al., 2019); being part of a like-minded community (Belleflamme et al., 2014; Kim and Petrick, 2020; Lukkarinen et al., 2016).

Research has also sought to identify the factors behind successful campaigns. These studies indicate that factors such as the personal attributes of the entrepreneur (Shafi, 2019); communication strategy (Lukkarinen et al., 2016; Müllerleile and Joenssen, 2015); social capital (Brown et al., 2019); and team characteristics (Bapna, 2017; Bollaert et al., 2017; Shafi, 2019) are all important factors. Research has shown that the interaction with investors, particularly at the initial stages of the campaign, has been shown to be an important factor in the success or failure of the campaign (see for example Kim and Petrick, 2020 and Brown et al., 2019).

As research into crowdfunding has developed, an area that has been the subject of recent debate is the link between crowdfunding and the development of hightechnology innovative start-ups. As far back as Schumpter (1912) innovation and new business development have been linked with economic output and growth (Holmberg, 2016). Recently, Audretsch et al. (2020) argue that innovative and high technology start-ups create new industries and considerable economic and societal impact.

As noted by Herve and Schwienbacher (2018), it is in this area that crowdfunding offers significant gains. Typically, new technology start-up businesses tend to be considered risky, making traditional sources of finance a major challenge. Moreover, because these firms can be relatively small, without a trading history, they face with additional problem of significant asymmetry information problems (Carpenter and Peterson, 2002; King and Levine 1993).

In the context of the above, this research seeks to add to the growing debate within the academic community (for example, Eldridge, et al., 2019; Herve and Schwienbacher, 2018) on the link between crowdfunding, innovation, and enterprise development. Namely, what is the role and potential of crowdfunding in assisting early stage funding for small innovative start-ups. Using a case study analysis, this paper traces the motivations, challenges and opportunities of crowdfunding by a new technology startup. The aim is to extend our understanding of the link between crowdfunding, innovation and entrepreneurship. In this regard, the research seeks to address a

International Journal of Management and Applied Research, 2021, Vol. 8, No. 1 
number of specific questions, from the perspective of the main protagonist - a start-up technology entrepreneur, namely:

- The motivation and decision to engage in crowdfunding;

- The challenges in engaging in a crowdfunding campaign with an innovative business idea;

- The benefits and opportunities crowdfunding offers to early stage, new innovative start-up entrepreneurs;

- The lessons learnt from the experience.

The paper proceeds as follows. The next section provides a summary of the methodology and data collection employed. The following section provides context to the study and traces the story of the entrepreneur from the initial idea to product development. In 2018, having conducted some early market testing of the product, the entrepreneur - Simon - was faced with the challenge of raising $€ 50,000$ to fund initial production. The case examines the challenges in trying to secure funding as a start-up enterprise with an innovative product and the factors that drove the decision to crowdfund the idea. Preparing for the campaign and the challenges this presented and the impact unforeseen events had following the campaign launch are also examined. The case study then moves on to discuss the lessons learnt as the entrepreneur reflects on the experience in an attempt to provide insights into how to successfully navigate this new funding arena. The paper concludes with the main conclusions and insights from the case along with a discussion on limitations and future research.

\section{Methodological Approach}

Case study research design is a widely adopted methodology in social science research (Harrison et al., 2017). Typically, it involves an in-depth, multi-dimensional approach involving the use of multiple sources of data and methods (Merriam, 2009; Stake, 2006; Yin, 2014) in an attempt to try and understand a particular issue in a real life setting. Numerous authors have examined the value and use of case study methodology, most notably Yin, (2014); Stewart (2014); Green and Thorogood, (2009); and Stake (2006).

For the purposes of this case the approach adopted was an instrumental case study approach. Consistent with the work of Stake (2006), the instrumental approach uses a particular case or event to allows the researcher to gain "a broader appreciation of an issue of phenomenon" (Crowe et al. $(2011$, p. 2). The information was drawn from a variety of sources including in depth interviews conducted with the entrepreneur over a period of seven months, supplemented with information from the company's social media pages, news articles and company website.

\section{History of the Company}

In 2003, Simon moved to Ireland having spent the previous 20 year working in the UK. Originally from Hong Kong, Simon worked in the catering industry for most of his life, with little or no entrepreneurial experience. His decision to move to Ireland was driven in equal parts by his love of the country and by his perception of Ireland

International Journal of Management and Applied Research, 2021, Vol. 8, No. 1 
having a supportive entrepreneurial and innovative business culture. He was convinced that Ireland would provide a very good environment in which he could explore and develop his innovative business idea.

Over the subsequent years, he began focusing on turning his idea into reality. Deeply concerned about environmental issues and fascinated with "the power steering in his father's truck", he poured his passion and energy into making a Super Bicycle. The main component of the SuperCycle - called SuperWheel - would be environmentally friendly and would give the user the ability to convert human power (weight) into energy that would improve cycling efficiency. It relies on an innovative technology entitled Weight to Energy Conversion Technology (WTECT). The key component of the SuperWheel is made up of two innovative mechanisms: the external springs and the internal drive. The combination of these two systems can generate additional energy to assist pedalling and provides the only alternative to assistive cycling with a battery.

As documented in Table 1, the SuperWheel project commenced in 2014. Over the next two years, working with two Irish colleges - Dundalk Institute of Technology (DKIT) and Dublin City University (DCU) - and with grant funding in the form of an Innovation Voucher (the Innovation Voucher scheme was developed to build linkages between public knowledge providers (i.e. higher education institutes, public research bodies) and SMEs. Innovation Vouchers worth $€ 5,000$ are available to assist a business to explore a business opportunity or problem with a registered knowledge provider) to the value of $€ 5000$ from Enterprise Ireland, Simon achieved a design breakthrough with the first initial prototype KM1. Subsequent ongoing development and testing with researchers in DCU and a licensing agreement on the EasyPedal with a local engineering company resulted in the computerized evaluation confirmed the benefits of the new idea - that by using $10 \mathrm{~kg}$ active weight, the system generated a moment ranging in the size of 7.3 to $7.8 \mathrm{Nm}$ that is more than 30 percent energy efficiency improvement over a standard wheel.

Table 1: Timeline from Inception to Launch of Crowdfunding Campaign

\begin{tabular}{ll}
\hline Date & Activity \\
\hline $\begin{array}{l}\text { 2014 } \\
\text { Mar } \\
\text { Sep }\end{array}$ & $\begin{array}{l}\text { The SuperWheel concept was born } \\
\text { Development testing with a wooden prototype }\end{array}$ \\
$\begin{array}{ll}\text { 2015 } \\
\text { Mar }\end{array}$ & $\begin{array}{l}\text { Awarded R\&D funding from Enterprise Ireland and began to } \\
\text { work with Dublin City University (DCU) }\end{array}$ \\
2016 & $\begin{array}{l}\text { The virtual prototyping-computerised evaluation and prototype } \\
\text { Feb }\end{array}$ \\
Jun & $\begin{array}{l}\text { Pesign completed by DCU } \\
\text { Automation, County Down, N Ireland and DCU }\end{array}$
\end{tabular}

International Journal of Management and Applied Research, 2021, Vol. 8, No. 1 
2017 Design breakthrough with prototype KM1. Ongoing

Oct development and testing continues

\begin{tabular}{ll}
2018 & Project receives support from Climate KIC Accelerator \\
Mar & $\begin{array}{l}\text { Pre-launch and public trial event held in Dundalk Institute of } \\
\text { Technology(DKIT) }\end{array}$ \\
Jul & $\begin{array}{l}\text { Successfully completed } 23 \text { trial runs with fantastic feedback } \\
\text { from users }\end{array}$ \\
Nug & $\begin{array}{l}\text { The final prototype KM9 completed } \\
\text { Crowdfunding campaign (Launched) }\end{array}$ \\
\hline
\end{tabular}

In 2016 and 2017 Simon took the next step towards commercialisation, and enrolled on the New Frontiers programme phase 1 and phase 2 at DKIT. This programme is an enterprise development programme funded by Enterprise Ireland provided at the Regional Development Centre (RDC), which is an incubation hub attached to DkIT. It was a crucial step in launching the 'SuperWheel' concept. With the help of the Enterprise Development Manager at the RDC Simon spent the next two years understanding the business and marketing aspects of the business and developing and testing the project.

In July 2018 Simon had successfully market-tested the product when he spent time engaging with local bicycle stores, along with on-line surveys, trial runs with users providing the necessary consumer feedback. The feedback was overwhelmingly positive. With an award from Climate KIC Accelerator in early 2018, Simon decided to launch the first model the 700c model of SuperWheel that could be used on Roads and Trekking bikes. To achieve their ambition, the company needed $€ 50,000$ to fund the first production run.

\section{The challenge of accessing funding as a start-up}

Accessing funding is a universal problem for entrepreneurs. Starting a business and securing funding is a major challenge for entrepreneurs throughout the world. This is particularly the case in rural regions and less developed countries such as Africa and Asia (Chae et al 2020) with less developed financial markets. In addition, securing funding for innovative ideas has been identified as problematic resulting in a funding gap for innovative start-ups (Hervé and Schwienbacher, 2018).

In the context of Ireland, despite having a really dynamic and supportive entrepreneurial culture, accessing funding is still a major challenge for several reasons. Firstly, the funding sector for business in Ireland is problematic largely due to the fact that the three main banks -BoI, AIB and Ulster Bank - have a triopoly on lending to the SME sector. The latter control some $95 \%$ of SME funding. Secondly, research from the Central Bank of Ireland Report (2018) indicates that Irish SMEs are about 50 percent less likely to apply for bank funding than their EU counterparts, and that bank rejection rates for SME loans is more than twice the rate in comparator EU countries. While enterprise support agencies, venture capitalist (VCs) and business angel markets have increasingly played an important part, this is not without its challenges (Hellman,

International Journal of Management and Applied Research, 2021, Vol. 8, No. 1 
1998). VCs can often seek high levels of ownership and control of the business, with an expectation of a high rate of return. Within the last ten years, access to funding has certainly improved, but there are still major obstacles for many start-up or early stage businesses. For example, in terms of crowdfunding, research by the Department of Finance 2018 acknowledged that the crowdfunding market in Ireland was relatively small accounting for less than 0.4 percent of the SME finance market. The comparable figure for the UK was 12 percent. The report also recognises the potential of crowdfunding for Irish entrepreneurs is not fully exploited due to a lack of information among SME and entrepreneurs in the value of non-banking finance.

While Simon has secured grant funding from Enterprise Ireland's Innovation Voucher, raising private funding from investors or the banking sector was a totally new challenge. His business needed to get a large batch order to start production, so he sought to raise funds to get his product to the market. He had successfully developed what he felt was a great product and positive market feedback from consumer tests meant that the next step was to commence production. As an early stage start-up he had limited resources and supports to obtain sufficient funds in order to grow his business. The traditional funding sources from bank financing were not an option for Simon. According to Simon "If you are a limited company with a trading history and a business plan, bank funding is certainly an option, but in my case, as a start-up, the banks would not help me". The rejection occurred despite the fact that he was accepted for the Climate KIC Accelerator which included a $€ 10,000$ grant. Simon recounted his meeting with his local bank: "Despite having emails confirming the acceptance of the Climate KIC Accelerator, the bank refused a $€ 3000$ overdraft facility". Citing friends who applied for loans from the bank and were put "under pressure to provide personal guarantees" he looked to go outside traditional funding sources.

The challenges facing technology based start-ups in accessing funding have been widely acknowledged. According to Cowling et al (2020), it is difficult for technology start-ups to receive loans from external financial institutions. Small businesses especially Tech start-ups are more likely to require access to bank loans in order to expand (Colombo and Grilli, 2007). Moreover, as start-ups, it is challenging for them to prove their personal creditworthiness and get their credit history proved (Colombo and Grilli, 2007).

From the outset, Simon was reluctant to approach venture capitalist (VCs) and business angels (business angels, commonly referred to "informal private investors", are private individuals who invest capital in a business during the early stage of development. Venture funding involves firms or individuals who provide capital, typically for a certain share of the start-up. Simon considered venture capitals but felt it was too risky "VCs often take a certain percentage of shares out of the company. It was too risky and you could lose control of the company". He felt that at this stage it was not the right move.

\section{Entering the world of Crowdfunding}

Crowdfunding is a term that has become a powerful yet disruptive force for entrepreneurs worldwide in accessing start-up funding. Typically, it involves raising

International Journal of Management and Applied Research, 2021, Vol. 8, No. 1 
funding from the crowd often referred to as backers. Money can be raised by a large number of individuals (so called backers) who each typically contribute a small amount, usually via the internet online to help entrepreneurs (and community projects) access much needed findings outside the traditional financial system.

Given the number of crowdfunding platforms, one of the first challenges facing a startup moving into the crowdfunding arena is to identify the most suitable platform for their product or company (Dushnitsky and Fitza, 2018). According to Brown et al. (2018), communications between funders and the crowds make crowdfunding much more complicated and time consuming than alternatives. Moreover, entrepreneurs need to find the right crowdfunding platform for their types of businesses and adopt crowdfunding as a planned financial method.

As Simon acknowledges when "you go on social media everyone is talking about Kickstarter and Indigegogo, but this is becoming a very crowded market, there are so many companies now in this space... even Inter Trade Ireland (a cross-border Trade and Business Development Body, funded by the Department of Business, Enterprise and Innovation in Ireland (DBEI) and the Department for the Economy (DFE) in Northern Ireland) has started crowdfunding". Trying to navigate this arena can be challenging and according to Simon "there are so many different types of crowdfunding available" it can be difficult to know which is most suitable to your particular product or concept.

He further notes that Kickstater is "the biggest, but it is all or nothing ... if your target is 6,000 euro, and if over the crowdfunding period of our or five weeks, you do not reach your target, you get nothing". However, Indiegogo has more flexibility and this is what attracted Simon to this platform. "Indiegogo, they do flexible funding. If you set up 6,000 euro, if you only have 5,900 or 5,000 or a smaller amount, you still can take it". Crowdfunding platforms differ in terms of the user friendliness, number of backers, with some offering different crowdfunding types (Herve and Schwienbacher, 2018). Indiegogo, for example, gives backers control over whether they want a fixed model or a flexible model. The other advantage according to Simon was the pre-order facility offered. He makes the point that "with pre-order, you do not have to sell equity in your company...you only sell the product". The pre-order facility gave him important information on potential sales which impacted on production costs. "Because we needed large batches of orders to start manufacturing, the pre-sale crowdfunding was the best option for us ...... as it enables you to get some money upfront". This statement is supported by earlier research which suggests that using the pre-order to sell the product on the crowdfunding platform allows the entrepreneurs to be funded by those who are interested in the product (Belleflamme et al., 2015).

\subsection{The Pre-Launch}

As noted by $\mathrm{Li}$ et al. (2016) there are three core elements to building a successful crowdfunding campaign are: storytelling including developing video(s) to explain the product; setting up rewards; and engaging social networks such as Facebook and Twitter. According to Simon "It seems simple, but the difficulty faced by most entrepreneurs is that they do not have the time and skill sets. There is significant time

International Journal of Management and Applied Research, 2021, Vol. 8, No. 1 
and energy involved before launching a crowdfunding campaign" Simon recounts the challenge of putting together the promotional videos, website which all play an important part in a campaign. According to Simon "your promotional video and website are your shop front so they need to be professional". This viewpoint is consistent with evidence from $\mathrm{Li}$ et al. (2017) which suggest that it is important for entrepreneurs to plan a steady stream of contents (stories, videos), updates, offers and opportunities via social media in crowdfunding campaigns. Simon recalled that putting together a short promotional video can be a challenge as he had no knowledge in video design. Initially he worked with some students from DKIT to produce a video which was a start. Eventfully he bought a high end camera and with the help of a professional in the area, put together a short three-minute promotional video. However, he had other serious concerns.

This was his first crowdfunding campaign and as the launch date approached, Simon was very aware that the marketing material and product information, vital to the successful launch was not sufficient to attract the necessary backers. According to Simon "The Product design at the time was very basic, and lacked a convincing and wow factor". Plus, there was a lack of pre-launch marketing campaign. According to Simon the marketing campaign should have started "at least a few months before the crowdfunding campaign". This is consistent with research which suggests that to succeed in crowdfunding, entrepreneurs need to invest in and prepare seriously before launching a crowdfunding campaign (Appio et al., 2020; Honisch, et al., 2019).

In July, a serious accident soon after the pre-launch event held in DkIT caused a major disruption to the pre-launch crowdfunding campaign. An avid cycler, Simon was cycling close to College Green in Dublin, and had a serious accident, caused by a collision with a tram track. "I broke my arm in three places", Simon recounts and "I needed surgery" and "was off work for a while". In fact, Simon was off work for three months. The impact of all this, was that the SuperWheel crowdfunding campaign on Indiegogo, which was initially set for September, was delayed to November, one of the worst time for crowdfunding campaign. With little pre-campaign preparation caused by the surgery after the accident, Simon had serious concerns for the upcoming campaign launch.

\subsection{The Launch}

The crowdfunding campaign commenced in mid-November 2018 and ran for four weeks. Within the first two weeks Simon and his team were very aware that the campaign would not raise the necessary funds and from a financial perspective may not be successful. One of the problems he recounts was around the verification of the technology. According to Simon "the potential backers were sceptical about the SuperWheel Weight To Energy Conversion Technology which was ground-breaking technology" and "without a verified testing data from a respectable organization, we simply could not convince the backers". Successful crowdfunding takes a lot of work and preparation, and thus it might be essential for start-ups to gain better knowledge of its consumers especially when their products are new to the market (Belleflamme et al., 2015). Like many entrepreneurs he was undeterred. "This was my first crowdfund so I had to embrace it, and to use it as an opportunity for free exposure".

International Journal of Management and Applied Research, 2021, Vol. 8, No. 1 
As the crowdfunding campaign drew to a close, financially the campaign was not successful. "We have just approximately $€ 2000$ out from our target of 50,000. It had to be viewed as a failed campaign". After the four weeks' campaign, Simon refunded all the money raised on the campaign to his backers.

\section{Lessons learnt}

Looking back on the experience, Simon is overwhelmingly positive. Despite having not crowdfunded the money required to commence production, it was a turning point for the business. "There were huge benefits from the crowdfunding experience, the social media benefits were huge". Shortly after the crowdfunding launch, Simon's story was picked up by a number of media sources including Amag, BIGLOBE, BIKERUMOR! Cycling Weekly, Excite Japan, Irish Times, Irish Tech News, GIZMODO, and SIA Magazin. This led to hundreds of news stories and videos worldwide, and this was the result of global exposure of the project during the crowdfunding campaign (see for example, Figure 1 Media Report on SupwerWheel).

\section{Figure 1: Photo from Media Report on SuperWheel 體重越重越好騎：世界第一款用重量 轉換動能的車輪 SuperWheel}

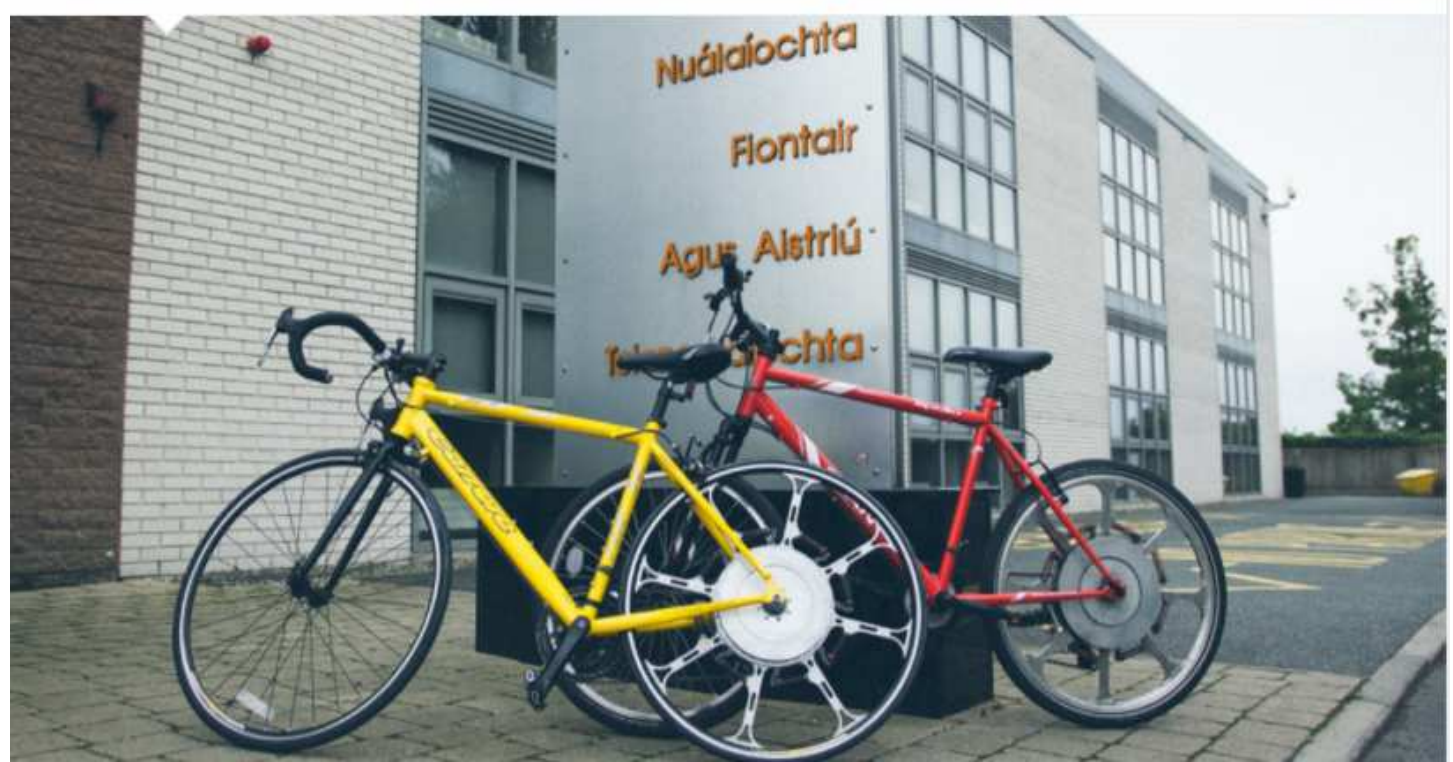

Source: Amag (2018)

Getting this exposure made it easier to reach global marketing channels and markets. According to Simon "the crowdfunding campaign gave the product global exposure around the world. It also helped the product to gain licensing agreements in many countries" Within a matter of months, Simon was approached by a number of

International Journal of Management and Applied Research, 2021, Vol. 8, No. 1 
companies looking to sign licensing agreements with the company. In early 2019, a French businessman travelled to Ireland to test the SuperWheel concept in Dundalk and became the first licensee. This was followed shortly with license agreements in Asia and North America and Canada. With a matter of months following the crowdfunding campaign, SuperWheel had signed licensing agreements in France, Japan, Hong Kong and Canada, and had secured the first 50 pre-sales orders to allow the first production and $€ 30,000$ investment to complete the Nation phase of the Patent application. These licensing agreements, orders and investment were all linked to the initial crowdfunding campaign.

Asked about the challenges in crowdfunding for entrepreneurs, according to Simon "the first time you crowdfund, there are so many unknowns". At the outset, he believes that understanding the mind-set of the potential backers/funders is crucial. According to Simon: "the people who support your product, they are not normal buyers. They are buying goods from you, because they are supporting your project, supporting your ideas". Typically, the crowd has its own preferences and biases, so that entrepreneurs' personal networks and business networks are vital to funding success (Brown et al., 2019). This is a fundamental difference between crowdfunding backers and normal customers. According to Simon, "building trust with the buyers, the backers is key". Building trust and making sure that the content you produce provides confidence to potential backers that you can produce the goods is a key aspect of the whole process. According to Simon: "you need to show them your product, your team.... It is not just about getting the money". For him, having secured a number of awards "helped build this credibility". This he considers all very important.

Simon also makes the point that not all projects should be crowdfunded. His advice is to "look at the types of crowdfunding out there and choose the one to suit your company -there is no one fits all". Simon makes the point that "most backers on crowdfunding are relatively young, in their mid-20s to mid-30s, early adopters, so it is important to understand your target market". Hence, different types of projects suit different types of crowdfunding platforms (Belleflamme et al., 2015). According to Simon, "you do need to do research to assess which one is most suitable for your project".

Asked about the potential risks and patent infringement, Simon is quick to advise "not to disclose your idea too early" and to "hold back on certain information". For Simon "the patent and copyright infringement was a major concern". Like many innovators, he has spent many years inventing a product, so initially it is best "to hold back certain information until you go to a later stage". Getting your patent application in place before you start your crowdfunding campaign is crucial, particularly for new technology products. Simon commenced the patent application in 2017and in Spring 2020, has just completed the National Phase of Patent application. According to Simon "is a long process, but one that is crucial". Entrepreneurs are often aware of the need to patent their projects that play a vital role in defending online imitation (Cowden and Young, 2020).

One of the major challenges and learning from the experience was the skill set required around the marketing and promotional activities central prior to the crowdfunding

International Journal of Management and Applied Research, 2021, Vol. 8, No. 1 
campaign. Simon recounts his experience as a start-up, "you can't afford to have a marketing company" and "you have to manage all the social media yourself, you constantly do updates by yourself and build a good portfolio and promotional video and introduce your product is a major step". Going forward he feels that more training and education on the critical processes of crowdfunding and the importance of communication and social networks in a successful crowdfunding campaign would be vital. "I do think in Ireland you should have One-Stop-Shop or at least have advisors or specialists in this area". He also points to the need for more success stories of crowdfunding. This according to Simon would "encourage more people to do it. Looking at how other companies do on Kickstarter campaigns, that's how we learned things from them."

The other piece of advice from Simon is "Do not be afraid". Was he afraid of losing his reputation by not reaching the fundraising targets? For Simon, the worst thing is to "never try". Simon makes the point that "for entrepreneurs, we do not expect when we do everything that is needed to be successful. You go back to analyse what it went wrong and how to avoid the same mistake in the future". Simon is acutely aware that to successfully navigate the crowdfunding arena requires strong belief in your product and idea. He recounts the "colourful language" he received on some social media posts, and notes that you need to be "resilient". He views crowdfunding as an "adventure". Certainty for this entrepreneur it has been a success story. At the time of this case, the company has its first production, with Super-Wheel bicycles now on the road.

\section{Conclusion and closing remarks}

Within the last 10 years, crowdfunding has emerged as a powerful but disruptive force within the financial landscape. According to Macht and Chapman (2019), crowdfunding is not only popular as a tool for start-ups that seek funding, but it also brings non-financial benefits to start-ups such as market validation, obtaining ideas and receiving feedback. The mass appeal of crowdfunding is that it allows anyone who is willing to put their idea into the public domain to raise funds from anywhere in the world, via online platforms. For entrepreneurs, particularly in the technology or with an innovative idea, crowdfunding offers huge potential in this regard.

This case study examines the experience of one entrepreneur who attempted to crowdfund the money required to commence production of his innovative product. Due to an unforeseen accident the campaign was unsuccessful financially, but the nonfinancial gains resulted in the company securing pre-order sales which eventually enabled the entrepreneur to commence production and successfully launch the company.

The key takeaways from this case can be summarized as follows. There is no doubt that entering the world of crowdfunding is challenging and takes time, determination and a specific skill set. In the words of this entrepreneur "there are so many unknowns". According to Simon, crowdfunding involves a huge "learning curve" and requires "considerable time, skills and commitment. It takes considerable time to build trust between backers, developing a good image of the product, promotional skills and

International Journal of Management and Applied Research, 2021, Vol. 8, No. 1 
to understand details of costs and components and manufacturing and the logistics process".

In terms of the key advice for anyone considering crowdfunding, this case highlights the importance of building trust with the backers and the marketing and communication skills required both at the pre and launch period. Simon also makes the point that crowdfunding requires a specific skill set in terms of communicating and managing all marketing communications such as social media updates associated with the campaign. For Simon, more education and training in this area and the development of a "one stop shop" in terms of guidance and supports for aspiring entrepreneurs would be a major step forward. It is also important to recognise that crowdfunding is not suitable for every business and there is a need to understand the different crowdfunding platforms, due diligence and the importance of understanding the mind-set of potential backers.

Despite the challenges, for those willing to enter this dynamic environment, the gains can be significant. Although the campaign was not financially successful, the nonfinancial benefits in terms of the marketing exposure far surpassed the entrepreneur's expectations and ultimately led to the development of the business. According to Simon, "it was a major turning point for the business". The global media coverage resulting from the campaign led to hundreds of news stories and videos worldwide, which resulted in the company signing licensing agreements to sell the product in several countries. This was all due to the initial crowdfunding campaign.

A key takeaway from this case study is the potential crowdfunding offers innovative, start-ups. The case is supported by earlier research (see for example Herve and Schwienbacher, 2018) that the funding gap technology based businesses can be mitigated by crowdfunding. Moreover, the non-financial benefits associated with this funding platform in terms of market feedback and validation cannot be underestimated. As it documented in this case analysis, the crowdfunding campaign ultimately led to the company securing license agreements on a global scale.

\subsection{Limitations and Future Directions}

This case study seeks to provide new insights into the challenges and opportunities crowdfunding present for an innovative start-up entrepreneur in the technology sector. The evidence is based on an in-depth analysis of one entrepreneur's journey. Despite the insights gained, there are a number of limitations to this study, which offer opportunities for future research. First, the study is based on an in-depth analysis of one entrepreneur's experience. Whether the findings can be generalised to innovative businesses and start-ups generally remain to be shown. For example, an area for future research is the extent to which innovative or technology related entrepreneurs concur with the findings of this study. Second, the study focuses on trying to understand crowdfunding from the perspective of the entrepreneur. The growth in the number of crowdfunding platforms in recent years has meant that in the coming years, crowdfunding is likely becomes a more pervasive funding source within the entrepreneurship eco-system. It is thus important to continue explore the role of these platforms and funders. Finally, in the innovative start-ups sphere, there is a need to

International Journal of Management and Applied Research, 2021, Vol. 8, No. 1 
explore in greater detail the link between crowdfunding, innovation and enterprise creation.

\section{References}

1. Agrawal, A., Catalini, C. and Goldfarb, A. (2015), "Crowdfunding: geography, social networks, and the timing of investment decision". Journal of Economics \&

Management Strategy, Vol. 24, No. 2, pp. 253-274. https://doi.org/10.1111/jems.12093

2. Appio, F. P., Leone, D., Platania, F. and Schiavone, F. (2020), "Why are rewards not delivered on time in rewards-based crowdfunding campaigns? An empirical exploration", Technological Forecasting and Social Change, Vol. 157, pp. 1-9. https://doi.org/10.1016/j.techfore.2020.120069

3. Audretsch, D., Colombelli, A., Grilli, L., Minola, T. and Rasmussen, E. (2020). "Innovative start-ups and policy initiatives", Research Policy, Vol. 49, No. 10, pp. 1-14. https://doi.org/10.1016/j.respol.2020.104027

4. Bapna, S. (2017), "Complementarity of Signals in Early-Stage Equity Investment Decisions: Evidence from a Randomized Field Experiment", Management Science, Vol. 65, No. 2, pp. 459-954. https://doi.org/10.1287/mnsc.2017.2833

5. Belleflamme, P., Lambert, T. and Schwienbacher, A. (2014). "Crowdfunding: Tapping The Right Crowd", Journal of Business Venturing, Vol. 29, No. 5, pp. 585-609. https://doi.org/10.1016/j.jbusvent.2013.07.003

6. Bollaert, H., Leboeuf, G. and Schwienbacher, A. (2020), "The narcissism of crowdfunding entrepreneurs", Small Business Economics, Vol. 55, pp. 57-76. . https://doi.org/10.1007/s11187-019-00145-w

7. Brown, R., Mawson, S. and Rowe, A. (2019), "Start-ups, entrepreneurial networks and equity crowdfunding: A processual perspective", Industrial Marketing $\begin{array}{llll}\text { Management, } & \text { Vol. } & 80, & \text { pp. }\end{array}$ https://doi.org/10.1016/j.indmarman.2018.02.003

8. Brown, R., Mawson, S., Rowe, A. and Mason, C. (2018), "Working the crowd: Improvisational entrepreneurship and equity crowdfunding in nascent entrepreneurial ventures", International Small Business Journal, Vol. 36, No. 2, pp. 169-193. https://doi.org/10.1177\%2F0266242617729743

9. Bruton, G., Khavul, S., Siegel, D. and Wright, M. (2015), "New Financial Alternatives in Seeding Entrepreneurship: Microfinance, Crowdfunding, and Peerto-Peer Innovations", Entrepreneurship Theory and Practice, Vol. 39, No. 1, pp. 9-26. https://doi.org/10.1111\%2Fetap.12143

10. Burtch G., Ghose A. and Wattal S. (2013), "An empirical examination of the antecedents and consequences of contribution patterns in crowd-funded markets", Information System Research, Vol. 24, No. 3, pp. 449-519. https://doi.org/10.1287/isre.1120.0468

11. Bürger, T. and Kleinert, S. (2020). "Crowdfunding cultural and commercial entrepreneurs", Small Business Economics, https://doi.org/10.1007/s11187-02000419-8

International Journal of Management and Applied Research, 2021, Vol. 8, No. 1 
12. Central Bank of Ireland (2018), SME Market Report 2018, [Online] Available at: https://www.centralbank.ie/docs/default-source/publications/sme-marketreports/sme-market-report-2018.pdf?sfvrsn=6 (access on 15 December 2020).

13. Chao, E. J., Serwaah, P., Baah-Peprah, P. and Shneor, R. (2020), "Crowdfunding in Africa: Opportunities and Challenges", In: Shneor R., Zhao L., Flåten BT. (eds) Advances in Crowdfunding. Cham: Palgrave Macmillan, pp. 319-339. https://doi.org/10.1007/978-3-030-46309-0_14

14. Colombo, M. G. and Grilli, L. (2007), "Funding gaps? Access to bank loans by high-tech start-ups", Small Business Economics, Vol. 29, pp. 25-46. https://doi.org/10.1007/s11187-005-4067-0

15. Cowden, B. J. and Young, S. L. (2020), "The copycat conundrum: The doubleedged sword of crowdfunding", Business Horizons, Vol. 63, No. 4, pp. 541-551. https://doi.org/10.1016/j.bushor.2020.03.012

16. Cowling, M., Liu, W. and Zhang, N. (2020), "In the post-crisis world, did debt and equity markets respond differently to high-tech industries and innovative firms?", International Small Business Journal: Research Entrepreneurship, https://doi.org/10.1177\%2F0266242620947281

17. Crowe, S., Cresswell, K., Robertson, A., Huby, G., Avery, A. and Sheikh, A. (2011), "The case study approach", BMC Medical Research Methodology, Vol. 11, Article 100. https://doi.org/10.1186/1471-2288-11-100

18. Dushnitsky, G. and Fitza, M. A. (2018), "Are we missing the platforms for the crowd? Comparing investment drivers across multiple crowdfunding platforms", Journal of Business Venturing Insights, Vol. 10, pp. 1-10. https://doi.org/10.1016/j.jbvi.2018.e00100

19. Eldridge, D., Nisar, T. M. and Torchia, M. (2019). "What impact does equity crowdfunding have on SME". Small Business Economics, https://doi.org/10.1007/s11187-019-00210-4.

20. Estrin, S., Gozman, D. and Khavul, S. (2018), "The evolution and adoption of equity crowdfunding: entrepreneur and investor entry into a new market", Small Business Economics, Vol. 51, pp. 425-439. https://doi.org/10.1007/s11187-0180009-5

21. Galkiewicz, D. and Galkiewicz, M. (2018), Crowdfunding Monitor 2018 [Online], available

at: http://www.fh.kufstein.ac.at/content/download/3537648/file/crowdfundingmonitor 2018.pdf (access on 15 December 2020).

22. Gedda, D., Nilsson, B., Sathen, Z. and Soilen, K. S. (2016), "Crowdfunding: finding the optimal platform for funders and entrepreneurs", Technology Innovation Management Review, Vol. 6, No. 3, pp. 31-40. http://doi.org/10.22215/timreview/973

23. Green, J. and Thorogood, N. (2009), Qualitative Methods for Health Research, Los Angeles: Sage.

International Journal of Management and Applied Research, 2021, Vol. 8, No. 1 
24. Harrison, H., Birks, M., Franklin, R. and Mills, J. (2017), "Case Study Research: Foundations and Methodological Orientations", Forum: Qualitative Social Research, Vol. 18, No. 1, pp. 1-17.

25. Hellman, T. (1998), "The Allocation of Control Rights in Venture Capital Contracts", The RAND Journal of Economics, Vol. 29, No. 1, pp 57-76. https://doi.org/10.2307/2555816

26. Herve, F. and Schwienbacher, A. (2018), "Crowdfunding and innovation", Journal of Economic Surveys, Vol. 32, No. 5, pp. 1514-1530. https://doi.org/10.1111/joes.12274

27. Holmberg, J. (2016), Crowdfunding and Economicmic Growth: Potential effects on Investment Efficiency, Bachelor Thesis [Online] Available at: http://www.divaportal.org/smash/get/diva2:950979/FULLTEXT01.pdf (accessed on 5 September 2020).

28. Honisch, E., Harrington, R. J. and Ottenbacher, M. C. (2019), "Crowdfunding: Preparation considerations and success factors for the German restaurant sector", International Journal of Hospitality \& Tourism Administration, Vol. 20, No. 2, pp. 182-205. https://doi.org/10.1080/15256480.2017.1359733

29. Kickstartarter (2020), Stas [Online] Available at: https://www.kickstarter.com/help/stats (accessed on 17 November 2020).

30. Kim, M. J. and Petrick, J.F. (2020), "The Effect of Herding Behaviors on DualRoute Processing of Communications Aimed at Tourism Crowdfunding Ventures", Journal of Travel Research. https://doi.org/10.1177/0047287520919515

31. King, R. G. and Levine, R. (1993), "Finance, entrepreneurship, and growth: Theory and evidence", Journal of Monetary Economics, Vol. 32, pp. 513-542. https://doi.org/10.1016/0304-3932(93)90028-E

32. Kuppuswamy V. and Bayus B. L. (2018), "A review of crowdfunding research and findings", in Golder P. N., Mitra D. (Eds), Handbook of Research on New Product Development, Cheltenham: Edward Elgar Publishing, pp. 361-373.

33. Lehner, O. M. (2013), "Crowdfunding social ventures; a model and research agenda", Venture Capital: An International Journal of Entrepreneurial Finance, Vol.15, No. pp. 1-22. https://doi.org/10.1080/13691066.2013.782624

34. Li, Z., Jarvenpaa, S. L. and Pattan, N. (2016), "Cinetics: Fueling Entrepreneurial Innovations through Crowdfunding", The Journal of Information Technology Teaching Cases, Vol. 6, No. 2, pp. 75-83. https://doi.org/10.1057/s41266-0160005-z

35. Li, J. J., Chen, X. P., Kotha, S. and Fisher, G (2017), "Catching fire and spreading it: A glimpse into displayed entrepreneurial passion in crowdfunding campaigns", Journal of Applied Psychology, Vol. 102, No. 7, pp. 1075-1090. https://doi.org/10.1037/ap10000217

36. Lukkarinen, A., Teich, J. E., Wallenius, H. and Wallenius, J. (2016), "Success drivers of online equity crowdfunding campaigns", Decision Support Systems, Vol. 87, pp. 26-38. https://doi.org/10.1016/j.dss.2016.04.006

International Journal of Management and Applied Research, 2021, Vol. 8, No. 1 
37. Macht, S. and Chapman, G. (2019), "Getting more than money through online crowdfunding", Asia-Pacific Journal of Business Administration, Vol. 11 No. 2, pp. 171-186. https://doi.org/10.1108/APJBA-05-2019-0101

38. Massolution (2015), The Crowdfunding Industry Report, [Online] Available at https://www.smv.gob.pe/Biblioteca/temp/catalogacion/C8789.pdf (Accessed on 17 November 2020).

39. Merriam, S. B. (2009), Qualitative research: A guide to design and implementation, San Francisco: Jossey-Bass.

40. Mollick, E. (2014), "The dynamics of crowdfunding: an exploratory study", Journal of Business Venturing, Vol. 29, No. 1, pp. 1-16. https://doi.org/10.1016/j.jbusvent.2013.06.005

41. Mordor Intelligence (2020), Crowdfundng Market: Growth, Trends and Forecasts (2020-2025) [Online] Available at: https://www.mordorintelligence.com/industryreports/crowdfunding-market [Accessed on 17 June 2020].

42. Müllerleile T. and Joenssen D.W. (2015), "Key Success-Determinants of Crowdfunded Projects: An Exploratory Analysis", In: Lausen B., Krolak-Schwerdt S., Böhmer M. (eds) Data Science, Learning by Latent Structures, and Knowledge Discovery. Studies in Classification, Data Analysis, and Knowledge Organization. Berlin: Springer, pp. 271-281. https://doi.org/10.1007/978-3-662-44983-7_24

43. Shafi, K. (2019), "Investors' evaluation criteria in equity crowdfunding", Small Business Economics, https://doi.org/10.1007/s11187-019-00227-9

44. Stake, R. E. (2006), Multiple Case Study Analysis. New York: Guilford

45. Statista (2020). Market size of crowdunding worldwide 2019 an 2026. [Online] available at: www.statista.com/statistics/1078273/global-crowdfunding-marketsize/\#StatisticContainer [Accessed on 22 November 2020].

46. Stewart, A. (2014), "Case study". Mill, J. and Birks, M., Qualitative methodology: A practical Guide, Thousand Oaks, CA: Sage, pp. 145-159.

47. Wald, A., Holmesland, M. and Efrat, K., (2019), "It Is Not All About Money: Obtaining Additional Benefits Through Equity Crowdfunding", The Journal of Entrepreneurship, Vol. 28, No. 2, pp. 270-294. https://doi.org/10.1177/0971355719851899

48. Yin, R. K. (2014), Case study research: Design and methods, 6th Ed., Los Angeles: Sage.

International Journal of Management and Applied Research, 2021, Vol. 8, No. 1 